\title{
Korelasi Antara Tingkat Minat Baca dengan Kompetensi Pengetahuan Pendidikan Kewarganegaraan
}

\author{
Ani Maulani1 ${ }^{*}$, I Made Tegeh², Putu Aditya Antara3 \\ 123 Jurusan Pendidikan Guru Sekolah Dasar, Universitas Pendidikan Ganesha, Singaraja, Indonesia
}

\begin{abstract}
Abstrak
Penelitian ini bertujuan untuk mengetahui pengaruh tingkat minat baca dengan kompetensi pengetahuan Pendidikan Kewarganegaraan siswa kelas V SD Gugus V Kecamatan Sukasada Kabupaten Buleleng.Penelitian ini menggunakan rancangan ex post facto dengan pendekatan korelasional. Populasi dalam penelitian ini adalah seluruh siswa kelas V SD di Gugus V Kecamatan Sukasada yang berjumlah 208 orang siswa. Sampel pada penelitian ini adalah 159 orang siswa yang ditentukan dari populasi menggunakan propotional random sampling. Metode pengumpulan data menggunakan teknik nontes dengan instrument dalam bentuk angket yang terdiri dari 22 pernyataan untuk pengambilan data minat baca. Sebelum angket diujicobakan dilakukan uji instrumen dengan uji validitas konstruk, uji validitas butir, dan uji reliabilitas.Data kompetensi pengetahuan Pendidikan Kewarganegaraan diperoleh dengan teknik pencatatan dokumen.Analisis data menggunakan statistik infrensial regresi sederhana. Hasil penelitian menunjukkan hubungan yang signifikan antara tingkat minat baca dengan kompetensi pengetahuan pendidikan Kewarganegaraan berdasarkan nilai thitung $=0.960>$ tabel $=0.130$. Hal ini terbukti bahwa minat baca berpengaruh baik pada kompetensi pengetahuan Pendidikan Kewarganegaraan. Dengan demikian, perhitungan analisis data membuktikan adanya hubungan yang positif dengan kompetensi pengetahuan Pendidikan Kewarganegaraan Siswa Kelas V SD Gugus V Kecamatan Sukasada Kabupaten Buleleng Tahun Pelajaran 2019/2020.
\end{abstract}

Kata Kunci:

Minat Baca, Kompetensi Pengetahuan Pendidikan Kewarganegaraan

\begin{abstract}
This research aimed to investigate the effect of reading-interest level toward civic education's knowledge competence of fifth-grade student cluster V Sukasada district, Buleleng regency. The design used was ex post facto with correlational approach. The research population were all fifth-grade students cluster V Sukasada district, Buleleng regency, with 208 students in total. The research sample were 159 students determined from the research population using propotional random sampling. Data collection method used was non-test technique with instrument in the form of questionnaire; consisted of 22 questions to gather reading-interest data. Before the questionnaire tested, it was done instrument testing through constructionvalidity test, item-validity test, and reliability test. Civic education's knowledge competence data were obtained by document-record technique. Analysis test using inferential-statistics analysis with simple-regression analysis. The research finding portrays the significant effect between reading-interest level and civic education's knowledge competence based on value $t_{\text {hitung }}=0.960>t_{\text {tabel }}=0.130$. Thus, it can be concluded that reading-interest presents significant effect toward civic education's knowledge competence of fifth-grade student cluster V Sukasada district, Buleleng regency.
\end{abstract}

Keywords:

Reading-Interest, Civic Education's Knowledge Competence 


\section{PENDAHULUAN}

Pendidikan memiliki peran dan fungsi yang sangat penting dalam kehidupan manusia. Pada prinsipnya, pendidikan diselenggarakan secara demokratis, terbuka, pembudayaan dan pemberdayaan, membangun, mengembangkan kreativitas, mengembangkan budaya membaca, menulis dan membilang pada setiap komponen pendidikan (Depdiknas, 2003). Melalui pendidikan manusia akan mendapatkan ilmu pengetahuan yang dapat mengembangkan setiap potensi manusia, yang dilakukan melalui kegiatankegiatan yang berpengaruh pada proses pembelajaran (Nurhaidah \& Musa, 2015).

Kompetensi ini bukan hanya pengetahuan yang pasif, melainkan atas apa yang telah diketahui.Kompetensi adalah penguasaan pengetahuan, sikap, dan keterampilan tentang suatu objek tertentu (mata pelajaran) (Lestari et al., 2017). Kompetensi juga merupakan perpaduan dari pengetahuan, keterampilan,nilai dan sikap yang direfleksikan dalam kebiasaan berfikir dan bertindak (Yaumi, 2017). Kompetensi juga memiliki kaitan terhadap hasil belajar siswa dalam proses pembelajaran. Sedangkan kompetensi pengetahuan merupakan alat untuk mengukur tingkat pencapaian atau penguasaan peserta didik dalam aspek pengetahuan yang meliputi ingatan atau hafalan, pemahaman, penerapan atau aplikasi, analisis, sintesis, dan evaluasi (Kunandar, 2013).Kompetensi pengetahuan dapat dinyatakan sebagai kompetensi pada kemampuan berpikir untuk mengukur tingkat penguasaan siswa. Dalam Permendikbud 104 tahun 2014, kompetensi pengetahuan dinyatakan dengan skor tertentu berkaitan dengan kemampuan berpikir dan dimensi pengetahuannya (Permendikbud, 2014). Kompetensi pengetahuan juga dinyatakan sebagai ranah kognitif yang mampu mengukur tingkat penguasaan siswa dalam 6 aspek pengetahuan yang berdasarkan Taksonomi Bloom oleh Anderson dan Krathwohl, yakni: mengingat (C1), memahami (C2), menerapkan (C3), menganalisis (C4), mengevaluasi (C5), dan menciptakan (C6).

Salah satu muatan materi yang dapat mengukur kompetensi pengetahuan adalah muatan materi Pendidikan Kewarganegaraan (PKn).Pendidikan Kewarganegaraan sendiri merupakan usaha sadar dan terencana dalam proses pembelajaran agar peserta didik secara aktif mengembangkan potensi dirinya untuk memiliki kecerdasan, kecakapan, keterampilan serta kesadaran tentang hak dan kewajiban sebagai warga negara, penghargaan terhadap hak-hak asasi manusia, kemajemukan bangsa, pelestarian lingkungan hidup, kesetaraan gender, demokrasi, tanggung jawab, ketaatan pada hukum, serta ikut berperan dalam peraturan global (Renda \& Widiastini, 2017). PKn sendiri termasuk pendidikan suatu mata pelajaran yang bertujuan untuk membentuk manusia Indonesia seutuhnya yang berlandaskan pancasila, undang-undang, dan norma-norma yang berlaku di masyarakat masih belum optimal disampaikan ke siswa, juga berfungsi sebagai penyalur nilai-nilai, norma, demokrasi, dan pancasila yang sangat kental dengan jati diri bangsa Indonesia(Andayani et al., 2019).Dalam proses pembelajarannya guru tidak hanya sekedar menjelaskan saja namun guru harus mampu membuat siswa paham terhadap materi PKn yang disampaikan sehingga nantinya bisa ia terapkan dalam kehidupan sehari-hari.

Mata pelajaran Pendidikan Kewarganegaraan (PKn) merupakan salah satu mata pelajaran yang diberikan di kelas $\mathrm{V}$ sekolah dasar dan madrasah.Dalam pradigma baru PKn, dinamika perkembangan kehidupan berbangsa dan bernegara yang ditandai oleh semakin terbukanya persaingan antar bangsa yang semakin ketat, maka bangsa Indonesia mulai memasuki era reformasi diberbagai bidang menuju kehidupan masyarakat yang lebih demokratis.sabagai bagian dari pendidikan, pembelajaran PKn memiliki peran penting dalam mencetak siswa yang berkualitas, yaitu manusia yang berfikir logis, kritis, kreatif, dan inisiatif dalam menanggapi masalah sosial dalam kehidupan masyarakat. Namun terkadang mata pelajaran Pkn sering dianggap sebagai mata pelajaran yang membosankan karena lebih menekankan pada kegiatan menghafal teori sehingga siswa siswa merasa malas untuk membaca buku pelajaran PKn. Kenyataannya, minat baca siswa-siswi saat ini nampak rendah.

"Rendahnya minat baca sangat berpengaruh terhadap keaktifan dan prestasi siswa" saat mengikuti pembelajaran dikelas (Gunawan \& Ign. Wagimin, 2013). Dampak yang dirasakan siswa akan kehilangan konsentrasi belajar, banyak mengalami masalah dalam memahami materi pembelajaran. minimnya wawasan yang diketahui oleh siswa. ini dapat menjadi suatu kekhawatiran yang cukup menngharuskan terciptanya sauatu penanggulangan yang mampu meredanya. Berdasarkan hasil wawancara, observasi yang dilakukan dengan masing-masing wali kelas V di Gugus V Kecamatan Sukasada pada tanggal 18, dan 19 Oktober 2019, maka siswa kelas V diperoleh informasi, yaitu: 1) kondisi dilapangan masih terdapat siswa yang memiliki tingkat minat baca yang kurang terutama pada mata pelajaran Pendidikan Kewarganegaraan, 2) proses pembelajaran yang kurang efektif membuat siswa merasa bosan dan malas untuk memahami materi dengan membaca, 3) siswa kurang aktif dalam proses pembelajaran, 4) kurang mendengarkan instruksi guru untuk kegiatan literasi, 5) siswa pasif dalam proses pembelajaran, kurang lengkapnya fasilitas belajar yang menunjang pembelajaran siswa. 
Berdasarkan hasil observasi tersebut, bahwa memang benar kompetensi pengetahauan pendidikan kewarganegaraan siswa rendah, karena faktor utamanya adalah masih kurang optimalnya minat baca siswa yang tidak mendengarkan intruksi guru untuk melakukan kegiatan literasi.

Dalam Kegiatan belajar, salah satu kegiatan utama dalam belajar mengajar adalah kegiatan membaca. Berdasarkan kegiatan membaca di sekolah ataupun dilingkungan masyarakat, tingkat kemampuan membaca dapat dibedakan atas tujuh tingkatan, Sulistyo-Basuki (Kasiyun, 2015) membedakan tingkatan kemampuan membaca sebagai berikut: 1) orang yang tidak mampu membaca sama sekali, 2) orang yang memiliki kemampuan teratas dalam membaca, 3) orang yang sedang belajar dlam membaca, 4) orang yang melek huruf namun tidak membaca bacaan terbatas pada kehidupan sehari-hari, 5) orang yang melek huruf namun bukan pembacaan buku, 6) orang yang melek huruf namun bukan pembaca yang tepat, 7) orang yang melek huruf serta merupakan pembaca yang tetap. Minat baca menjadi kunci penting dalam kegiatan belajar mengajar, karena kompetensi seseorang dapat diraih dengan minat baca yang tinggi, bukan kegiatan menyimak atau mendengarkan. Definisi itu sejalan dengan (Wahadaniyah, n.d.) Minat baca adalah suatu perhatian yang kuat dan mendalam disertai dengan perasaan senang terhadap kegiatan membaca sehingga dapat mengarahkan seseorang untuk membaca dengan kemauannya sendiri atau dorongan dari luar (Ruslan \& Wibayanti, 2019) Minat baca tumbuh dari pribadi masing-masing seseorang, sehingga untuk meningkatkan minat baca perlu kesadaran dari setiap individu. Negara-negara maju adalah Negara yang minat bacanya sangat tinggi.

Sebagai proses berpikir, kegiatan membaca mencakup berbagai kegiatan mulai dari pengenalan kata sampai paragraph, "pemahaman terhadap isi bacaan, interpretasi ( tafsiran terhadap seseuatu), membaca dengan kritis, dan pemahaman kreatif"(Rahim, 2007). Kegiatan membaca yang dilakukan dengan baik sangat ditentukan oleh minat dari dalam peserta didik tersebut.Salah satu hal yang termasuk ke dalam faktor internal yaitu faktor minat.Minat merupakan suatu kecenderungan untuk memilih dan melakukan sesuatu hal atau obyek tertentu, di antara sejumlah obyek yang tersedia (Sudarsana, 2014). Minat juga adalah suatu rasa lebih suka dan rasa keterkaitan suatu hal atau aktivitas tanpa ada yang menyuruh (Slameto, 2010). Minat pada dasarnya adalah penerimaan akan sesuatu hubungan antara diri sendiri dengan sesuatu diluar diri. Suatu minat dapat diekspresikan melalui suatu pernyataan yang menunjukkan bahwa kita lebih menyukai suatu hal daripada yang lainnya. Ada beberapa faktor yang mempengaruhi minat yaitu faktor internal yang datang dari dalam diri dan faktor eksternal yang berasal dari uar seperti dorongan orang tua, dorongan guru dan rekan, tersedianya fasilitas dan lingkungan yang mendukung (Sudarsana, 2014).

Minat sangat berpengaruh terhadap kegiatan yang dilakukan, jika tidak adanya minat segala kegiatan akan dilakukan secara kurang efektif, efisien dan bersemangat. (Sudarsana, 2014) menyatakan bahwa minat dapat diartikan sebagai keinginan atau dorongan terhadap sesuatu yang sengaja dipehatikan dan diingatkan secara berulang-ulang terhadap sesuatu baik berupa orang, benda dan kegiatan yang ditambahkan dengan rasa ingin tahu untuk mengetahui dan mempelajari serta dpat dibuktikan lebih lanjut tentang suatu informasi atau sesuatu yang sudah didapatkan.

Tingginya minat baca siswa pada dasarnya suatu dasar yang menjadikan "siswa memiliki rasa suka atau ketertarikan terhadap suatu hal yang diminatinya diluar diri" dapat mendorong keinginan untuk belajar, sehingga memperoleh pemahaman dan penguasaan yang cepat serta mampu mengingat pembelajaran setelah proses belajar (Syardiansah, 2016). Minat baca adalah kecenderungan yang penuh disertai dengan usaha-usaha seseorang untuk membaca yang terwujud melalui kesediaan untuk mendapatkan berbagai bahan bacaan, membaca atas kemauannya sendiri sehingga dapat memberikan nilai yang baik dalam memperoleh informasi guna mengembangkan intelektul dan membangun pola komunikasi dengan diri sendiri Rahim (dalam Dalman, 2003).

Jika setiap individu memiliki minat yang tinggi terhadap sesuatu, maka hal ini akan memberikan dampak yang positif terhadap individu tersebut, contohnya adalah minat membaca. Membaca memberikan manfaat yang besar bagi pembacanya, yang mana mampu memperoleh informasi, pengetahuan baru, dan penambahan wawasan dan yang paling disadari atau tidak adalah peningkatan kualitas dan mutu kehidupan individu tersebut. Begitu pula dengan siswa, untuk mencapai kompetensi pengetahuan maka dapat dilakukan beberapa cara diantaranya bagaimana membangkitkan minat siswa untuk membaca dan belajar. Minat baca merupakan sikap positif dan adanya rasa keterikatan dalam diri anak terhadap aktivitas membaca dan tertarik terhadap buku bacaan (Sudarsana, 2014). Pemupukan minat baca haruslah dilakukan sejak dini agar seseorang akrab dengan buku dan akan mudah memahami materi dengan baik. Berdasarkan hasil penelitian yang dilakukan oleh Novrizta yang bertujuan untuk mengetahui bagaimana minat membaca siswa, bagaimana keterampilan menulis karangan narasi siswa, serta untuk mengetahui bagaimana hubungan antara minat membaca dengan keterampilan menulis karangan narasi siswa kelas V SD Negeri Bangkinang Kota, didapatkan hubungan yang positif antara minat baca dengan keterampilan menulis karangan narasi dengan nilai $r$ tabel yaitu 0,423 (taraf 
signifikansi 5\%, $\mathrm{N}=22$ ) dan $\mathrm{r}$ hitung sebesar 0,638 (Novrizta, 2018). Selain itu, Salma, Aini dan Mudzanatun juga melakukan penelitian yang dilatarbelakangi rendahnya minat baca siswa didunia pendidikan Indonesia. Penelitian ini menggunakan metode kualitatif dan meneliti dampak dari adanya kegiatan Gerakan Literasi Sekolah terhadap minat baca siswa (Salma \& dkk 2019). Berdasarkan hasil penelitian, diperoleh bahwa ada dampak positif dari adanya program Gerakan Literasi Sekolah pada minat baca siswa, melalui perhitungan angket minat baca dari siswa kelas III dan V yang tergolong tinggi.

Salah satu realitas yang ditemukan dalam pembelajaran oleh siswa, tidak sedikit siswa yang mengaku tidak suka dengan pembelajaran Pendidikan Kewarganegaraan (PKn), dikarenakan pembelajaran yang terkesan membaca dan menghafalkan materi-materi yang dipelajari.Padahal, tujuan dari pendidikan ini sangat mulia yakni menjadikan warga negara yang cerdas dan baik serta mampu mendukung keberlangsungan negara.Pelaksanaan pendidikan PKn di Indonesia masih mengalami beberapa kendala baik dari faktor sumber daya manusia, sarana dan prasarana, maupun kendala lain. Sebagai contoh yaitu kondisi pembelajaran PKn di sekolah-sekolah dasar di Gugus V Kecamatan Sukasada yang masih memiliki nilai kompetensi pengetahuan dan minat baca siswa yang rendah.

Penelitian ini bertujuan untuk mengetahui hubungan yang signifikan antara Tingkat Minat Baca dengan Kompetensi Pengetahuan Pendidikan Kewarganegaraan Siswa Kelas V SD Gugus V Kecamatan Sukasada Kabupaten Buleleng Tahun Pelajaran 2019/2020".

\section{METODE PENELITIAN}

Metode penelitian ini adalah penelitian kuantitatif jenis korelasi.Penelitian korelasi adalah penelitian yang dilakukan peneliti untuk mengetahui tingkat hubungan dua variabel atau lebih (Finisea \& Fajriyah, 2010). Rancangan enelitian ini pada dasarnya bertujuan untuk mengetahui korelasi antara tingkat minat baca siswa dengan penguasaan kompetensi pengetahuan PKn siswa SD kelas V di Gugus V Kecamatan Sukasada Kabupaten Buleleng, dengan tidak memanipulasi variabel bebas atau menggali fakta yang sudah terjadi sebelumnya sehingga penelitian ini tergolong penelitian ex post facto.Desain penelitian ini terdapat 9 sekolah yang diseleksi. Kelas yang diberikan penilaian adalah sampel yang diambil dari populasi kelas tersebut dengan menggunakan lembar angket atau kuisioner untuk mengukur tingkat minat baca siswa.

Populasi dalam penelitian ini berjumlah 208 siswa yaitu seluruh siswa kelas V Gugus V Kecamatan Sukasada.Pengambilan sampel dilakukan dengan menggunakan teknik "Proportionate Random Sampling" yaitu sampel yang memperhatikan perimbangan jumlah siswa kelas dengan perimbangan siswa di SD atau dengan kata lain memperhitungkan jumlah proporsi masing-masing kelas. Pengambilan sampel menggunakan teknik ini bertujuan untuk lebih menjamin representatif atau wakil sampel jika ternyata jumlah subyek yang terdapat dalam setiap wilayah tidak sama (Agung, 2014).Selanjutnya, sampel yang diambil adalah siswa kelas V Gugus V Kecamatan Sukasada yang keluar dari undian tersebut dengan jumlah sampel keseluruhan dari 9 sekolah tersebut adalah 159 orang siswa.

Metode pengumpulan data diperoleh untuk memperoleh data mengenai korelasi antara tingkat Minat Baca dengan Kompetensi Pengetahuan Pendidikan Kewarganegaraan Siswa Kelas V Gugus V Kecamatan Sukasada Kabupaten Buleleng tahun pelajaran 2019/2020 menggunakan instrument non tes yaitu kuisioner. Pengukuran minat baca pada penelitian menggunakan indicator-indikator yaitu: 1) Kesenangan membaca, 2) Kesadaran akan manfaat membaca, 3) Frekuensi membaca, dan 4) Kuantitas bacaan.untuk mengetahui adakah perubahan indicator minat baca siswa dalam membaca, maka diukur menggunakan non tes berupa kuisioner. Kuisioner yang digunakan merupakan kuisioner tertutup yang alternative jawabannya sudah ditentukan terlebih dahulu. Skala likert digunakan untuk mengukur kuisioner dalam penelitian ini, dimana skala ini digunakan untuk mengukur sikap, pendapat, dan persepsi orang atau sekelompok orang tentang fenomena sosial (Sugiyono, 2015).pengukuran kuisioner ini menggunakan skala likert yang artinya dlam penentuan skor atau nilai dibedakan berdasarkan kategori yakni: sangat setuju,setuju,ragu-ragu, tidak setuju,sangat tidak setuju. Rentangan nilai jawaban pada kuisioner terdapat pada Tabel 1.

Tabel 1 Rentangan Nilai Jawaban pada Kuisioner Minat Baca

\begin{tabular}{lccc}
\hline & Jawaban & \multicolumn{2}{c}{ Penyataan } \\
\cline { 2 - 3 } & \multirow{2}{*}{ Sangat Setuju } & 5 & Negatif \\
Setuju & 4 & 1 \\
Ragu-ragu & 3 & 2 \\
Tidak Setuju & 2 & 3 \\
\end{tabular}


Pernyataan yang ada pada lembar kuisioner dijawab oleh siswa diberikan skor sesuai dengan jawaban yang dipilih. Dalam menganalisis hasil uji coba instrumen, uji validitas minat baca menunjukkan 27 butir soal di kuisioner, namun hanya 22 butir soal yang valid. Digunakan rumus Alpha Cronbach dalam perhitungan uji reliabilitas instrumen sebesar 0,602.Dapat dikategorikan realibilitas yang kuat.

Selanjutnya metode teknik analisis data menggunakan metode analisis deskriptif dan metode analisis infrensial.sebelum melakukan analisis data terlebih dahulu diujikan prasyarat analisis yaitu: 1) uji normalitas sebaran data, 2) uji linieritas, dan 3) uji hipotesis, perhitungan uji hipotesis pada penelitian ini dengan menggunakan korelasi product moment.

\section{ANALISIS DAN PEMBAHASAN}

Hasil pada penelitian ini menunjukkan bahwa pada variabel minat baca digolongkan menjadi tiga kategori. kategoro tersebut tinggi, sedang, dan rendah. pada hasil penelitian ini memaparkan mengenai nilai rerata (mean),median, modus, standar deviasi, dan varians. berdasarkandata kompetensi pengetahuan PKn di tempat penelitian yang diperoleh melalui pencatatan dokumen merupakan data nilai ulangan Akhir Semester PKn siswa Sekolah Dasar kelas V pada semester ganjil 2019/2020 dengan jumlah sampel sebanyak 159 siswa. Jumlah kelas interval berdasarkan hasil perhitungan adalah 8, dengan masing-masing kelas memiliki panjang kelas interval sebesar 5.Sehingga, untuk tingkat perkembangan kognitif siswa berada pada nilai rata-rata sebesar 77.8 yang dapat berada dalam kategori nilai penilaian acuan patokan (PAP) yang cukup baik.

Instrumen minat baca yang digunakan dalam penelitian ini menggunakan non tes yaitu kuisioner yang berjumlah 22 butir pernyataan yang telah diuji validitas isi, validitas butir dan reliabilitas.pengisian kuisioner diberikan setelah melakukan pengamatan pada siswa pada tanggal 16 januari 2020 sampai dengan 13 Februari 2020. Jumlah total siswa dalam penelitian ini adalah 159 orang siswa. pada deskripsi data penelitian ini akan memaparkan hasil deskripsi minat baca. Selanjutnya untuk mengukur minat baca siswa diberikan kuisioner/angket.Rangkuman hasil analisis deskriptif disajikan pada Tabel 2.

Tabel 2. Hasil Analsis Deskriptif

\begin{tabular}{lcc}
\hline \multicolumn{1}{c}{ Statistik } & Minat Baca & Kompetensi Pengetahauan PKn \\
\hline Banyak Sampel & 159 & 159 \\
Mean & 80 & 77,8 \\
Median & 24,64 & 20,28 \\
Modus & 59,515 & 73,515 \\
Varians & 150,53 & 86,84 \\
Standar Deviasi & 12,269 & 9,31 \\
Skor Maksimum & 5 & 97 \\
Skor Minimum & 1 & 60 \\
\hline
\end{tabular}

Berdasarkan Tabel 2 distribusi data tingkat minat baca didapatkan hasil mean (M), median (Me), modus (Mo), varians, dan standar deviasi (SD) dari data hasil kuisioner tingkat minat baca, yaitu: mean $(\mathrm{M})=80$, median $(\mathrm{Me})=24,64$, modus $(\mathrm{Mo})=59,515$, varians $\left(\mathrm{SD}^{2}\right)=150,53$ dan standar deviasi $(\mathrm{SD})=$ 12,269 .

Berdasarkan Tabel 2, dapat diketahui bahwa Median>Modus $>$ Mean. Menggunakan penilaian skala lima teoritik dalam menentukan minat baca bernilai tinggi atau rendah.

1) Skor maksimal ideal = jumlah butir soal $x$ bobot soal $=27 \times 5=135$

2) Skor minimal ideal = jumlah butir soal $\mathrm{x}$ bobot soal $=27 \times 1=1$

3) Rata-rata hitung idealnya adalah $\mathrm{Mi}_{2}^{1}(135-27)=54$

4) Standar Deviasinya adalah $\operatorname{SD}_{\frac{6}{6}}^{\frac{1}{6}}(135-27)=18$

Tabel 3. Kategori Skala Lima Teoritik Minat Baca Siswa Kelas V

\begin{tabular}{cccc}
\hline \multicolumn{2}{c}{ Rentang Skor } & Hasil & Klasifikasi/Predikat \\
\hline $\mathrm{Mi}^{2}+1,5 \mathrm{SD} i \rightarrow$ & $\mathrm{Mi}+3,0 \mathrm{SDi}$ & $94,5-109$ & SangatBaik
\end{tabular}




\begin{tabular}{|c|c|c|c|}
\hline $\mathrm{Mi}+0,5 \mathrm{SDi} \longrightarrow$ & $<\mathrm{Mi}+1,5 \mathrm{SDi}$ & $79,5-94,5$ & Baik \\
\hline $\mathrm{Mi}-0,5 \mathrm{SDi} \rightarrow$ & $<\mathrm{Mi}+0,5 \mathrm{SDi}$ & $64,5-79,5$ & Cukup \\
\hline $\mathrm{Mi}-1,5 \mathrm{SDi} \rightarrow$ & $<\mathrm{Mi}^{-} 0,5 \mathrm{SDi}$ & $49,5-64,5$ & Tidak Baik \\
\hline $\mathrm{Mi}_{\mathrm{i}}-3,0 \mathrm{SD} \mathrm{i} \rightarrow$ & $<\mathrm{Mi}_{\mathrm{i}}-1,5 \mathrm{SD} \mathrm{i}$ & $27-49,5$ & Sangat TidakBaik \\
\hline
\end{tabular}

Berdasarkan Tabel 3. rerata (mean) dari minat baca yaitu 80 berada pada rentangan 79,5 94,5 sehingga minat baca termasuk kategori baik.

Sebelum dilakukan uji hipotesis, terlebih dahulu diujikan uji perasyarat yakni uji normalitas dan uji linieritas.Hasil uji normalitas dan linieritas terhadap tingkat minat baca siswa, sebagai berikut.

Berdasarkan hasil uji analisis perasyarat data pada penelitian ini, uji normalitas sebaran data dengan menggunakan uji normalitas Chi-Square $\left(X^{2}\right)$.

Tabel 4. Hasil Uji Normalitas Sebaran Data Tingkat Minat Baca

\begin{tabular}{ccccccc}
\hline No & $\begin{array}{c}\text { Kelas } \\
\text { Interval }\end{array}$ & fh\% & Fo & fo-fh & (fo-fh) & $\frac{(f o-f h)^{2}}{f h}$ \\
\hline 1 & $44-56$ & 3.6 & 0 & -0.36 & 0.13 & 0.036 \\
2 & $57-68$ & 21.6 & 38 & 16.4 & 268.96 & 12.45 \\
3 & $93-80$ & 54.3 & 44 & -10.3 & 106.09 & 1.95 \\
4 & $81-92$ & 54.3 & 47 & -7.3 & 54.29 & 0.99 \\
5 & $93-104$ & 21.6 & 30 & 8.4 & 70.56 & 3.26 \\
6 & $105-116$ & 3.6 & 0 & -0.36 & 0.13 & 0.036 \\
$\Sigma$ & Jumlah & 159 & - & - & & 18.72 \\
\hline
\end{tabular}

Berdasarkan Tabel 4, Hasil $X^{2}$ hitung kemudian dikonsultasikan ketabel chi-square pada taraf signifikansi 5\%. Berdasarkan taraf signifikansi 5\% dengan $\mathrm{dk}=\mathrm{n}-1=159-1=158$, didapat harga Chi-square tabel sebesar 188.33 dan Chi-square hitung sebesar 18.72, sehingga dapat disimpulkan bahwa ${ }^{2}$ hitung $18.72<2$ tabel 188.33 karena harga Chi-square hitung lebih kecil maka dapat disimpulkan data Minat Baca berdistribusi normal.

Berdasarkan hasil uji analisis perasyarat data pada penelitian ini , pengujian linieritas tercantum pada Tabel5.

Tabel 5.Hasil Uji Linieritas Data Kompetensi Pengetahuan PKn dengan Minat Baca

\begin{tabular}{|c|c|c|c|c|c|c|c|}
\hline \multicolumn{8}{|c|}{ ANOVA Table } \\
\hline \multirow{6}{*}{$\begin{array}{c}\text { Kompetensi } \\
\text { Pengetahuan } \\
\text { PKn * Minat } \\
\text { Baca }\end{array}$} & & & $\begin{array}{c}\text { Sum of } \\
\text { Squares }\end{array}$ & Df & $\begin{array}{l}\text { Mean } \\
\text { Square }\end{array}$ & $\mathrm{F}$ & Sig. \\
\hline & & (Combined) & 12992.344 & 40 & 324.809 & 52.648 & .000 \\
\hline & Between & Linearity & 12662.482 & 1 & 12662.482 & 2052.447 & .000 \\
\hline & & $\begin{array}{l}\text { Deviation from } \\
\text { Linearity }\end{array}$ & 329.862 & 39 & 8.458 & 1.371 & .101 \\
\hline & $\mathbf{W i}$ & Groups & 727.996 & 118 & 6.169 & & \\
\hline & & tal & 13720.340 & 158 & & & \\
\hline
\end{tabular}

Berdasarkan Tabel 5, Uji linieritas digunakan untuk mengetahui apakah hubungan dua variabel linier. Hubungan yang linier ditandai dengan adanya kenaikan skor pada suatu variabel lainnya.Berdasarkan analisis yang yang dilakukan dengan SPSS 22, didapatkan signifikansi Liniearity sebesar $0.000(\mathrm{p}<0.05)$ sehingga tingkat minat baca dengan kompetensi pengetahuan Pendidikan 
Kewarganegaraan memiliki hubungan linier. Sedangkan signifikansi Deviation from liniearity sebesar 0.101 ( $p>0.05$ ) sehingga tingkat minat baca dengan kompetensi pengetahuan Pendidikan Kewarganegaraan memiliki hubungan yang berarti.

Berdasarkan pengujian hipotesis yang telah dilakukan diperoleh nilai $\mathrm{r}_{\mathrm{xy}}=0.961$ yang artinya terdapat hubungan antara tingkat minat baca dengan kompetensi pengetahuan Pendidikan Kewarganegaraan Siswa Sekolah Dasar Kelas V di Gugus V Kecamatan Sukasada Kabupaten Buleleng 2019/2020. Besarnya nilai $r_{\text {tabel }}$ dapat diperoleh dengan derajat kebebasan $(\mathrm{df}=\mathrm{N}-2$ ), pada taraf signifikansi $5 \%$. dan diperoleh $\mathrm{df}=159-2=157$ dan diperoleh $\mathrm{r}_{\text {tabel }}$ sebesar 0.130 , sedangkan $\mathrm{r}_{\text {hitung }}=$ 0.961 . Hasil analisis data memperoleh koefisien determinasi $r^{2}=0,028$. Dikarenakan $r_{\text {hitung }}>r_{\text {tabel }}$ dan koefisien determinasi memberikan kontribusi sebesar $0,28 \%$ maka dapat dinyatakan terdapat hubungan yang signifikan antara tingkat minat baca dengan kompetensi pengetahuan Pendidikan Kewarganegaraan Siswa Sekolah Dasar Kelas V di Gugus V Kecamatan Sukasada Kabupaten Buleleng 2019/2020.

Minat atau keinginan yang dimiliki seseorang akan mendorong dirinya untuk menentukan masa depannya. Membaca merupakan salah satu keterampilan dari empat keterampilan berbahasa. Maka dari itu kegiatan literasi atau membaca sangat penting untuk ditanamkan dalam diri seseorang, karena dari membaca banyak hal yang bisa didapatkan salah satunya akan menambah wawasan. Minat baca harus dimiliki oleh setiap siswa yang mempelajari beberapa kompetensi dasar dalam suatu pembelajaran salah satunya adalah Kompetensi pengetahuan Pendidikan Kewarganegaraan. Jika tidak memiliki minat baca, maka siswa tersebut akan kesulitan untuk memahami materi pembelajaran tersebut.

Berkaitan dengan kurikulum yang diterapkan pada kurikulum 2013, yang didalamnya ada kegiatan literasi atau membaca.karena tujuan kurikulum 2013, menuntut siswa untuk berpikir kritis, kreatif, inovatif dan cepat tanggap, serta melatih dirinya untuk menumbuhkan keberanian diri dalam dirinya.

Upaya untuk meningkatkan kompetensi pengetahuan Pendidikan Kewarganegaraan dengan menumbuhkan minat baca siswa kelas V yakni: Pertama, pihak sekolah selalu memberikan sosialisasi, motivasi dan pengertian mengenai kegiatan literasi kepada guru maupun siswa agar prestasi siswa menjadi lebih baik. Kedua, membuat pojok baca di setiap pojok kelas, agar siswa lebih nyaman berada diruang kelas. Ketiga, Membuat jadwal kunjungan siswa ke perpustakan per kelas. Keempat, pihak sekolah berupaya menyediakan atau mengadakan lomba-lomba sebagai wadah siswa untuk berpatisipasi aktif dalam kegiatan membaca.

Rahim (dalam ) (KARIADI \& SUNARSO, 2016) juga berpendapat bahwa kecenderungan yang penuh yang disertai dengan usaha-usaha seseorang untuk membaca yang terwujud melalui kesediaan untuk mendapatkan berbagai macam bahan bacaan, membaca atas kemauannya sendiri sehingga dapat memberikan nilai yang baik dalam memperoleh informasi guna mengembangkan intelektual dan membangun pola komunikasi dengan diri sendiri.

Dilihat dari deskripsi hasil penelitian bahwa kompetensi pengetahuan Pendidikan Kewarganegaraan dengan korelasi tingkat minat baca siswa lebih baik dengan adanya perubahan yang signifikan. Membaca marupakan salah satu hal penting dalam segala macam proses pemebelajaran, melalui membacalah berbagai ilmu pengetahuan yang dapat mengantarkan pada kesuksesan yang bisa kita dapatkan (Arum Nisma Wulanjani \& Candradewi Wahyu Anggraeni, 2019). Slameto dalam (Syardiansah, 2016) menyatakan tingginya minat baca siswa pada dasarnya suatu dasar yang menjadikan"siswa memiliki rasa suka dan ketertarikan terdapa suatu yang diminatinya di luar diri" dapat mendorong keinginan untuk belajar, sehingga memperoleh pemahaman dan penguasaan yang cepat serta mampu mengingat pelajaran setelah proses belajar. Selaras dengan hasil penelitian yang dipaparkan oleh Sari yang membuktikan bahwa minat baca memiliki hubungan yang signifikan dengan hasil belajar IPS siswa dengan besarnya korelasi 0,633 dengan tingkat korelasi kuat $\left(r_{\text {hitung }} 0.633>r_{\text {tabel }} 0.195\right)$. Hal tersebut menunjukkan bahwa ada hubungan yang signifikan antara minat baca dengan hasil belajar IPS siswa dengan besarnya persentase hubungan minat baca dengan hasil belajar IPS yaitu $40.60 \%$ (Sari, 2016). Hasil penelitian yang dilakukan oleh Utami dan Bakhtaruddin, perpustakaan SDIT Iqra' Kota Solok dapat memperluas mengembangkan budaya membaca dan membantu siswa memperluas pengalamannya, berperan meningkatkan minat baca siswa. Perpustakaan SDIT Iqra' menyediakan koleksi buku-buku paket dari Departemen Pendidikan Nasional yang sesuai dengan kurikulum, dapat menunjang proses belajar mengajar disekolah (Utami \& Bakhtaruddin, 2012).

Hasil penelitian yang dilakukan oleh Kariadi, menganalisis hal-hal yang mempengaruhi hasil belajar PKn siswa baik secara parsial maupun silmultan, bahwa ada empat hal yang diduga berpengaruh terhadap hasil belajar PKn adalah minat baca, waktu belajar, sarana dan prasarana, dan kemampuan mengajar guru. Dengan hasil analisis regresi ganda yang menunjukkan nilai $r$ sebesar 0,952; F sebesar 652,044 yang berarti secar bersama-sama berpengaruh signifikan terhadap hasil belajar PKn dengan sumbangan efektif sebesar 90,(KARIADI \& SUNARSO, 2016) 
Persamaan penelitian-penelitian sebelumnya dengan penelitian yang diteliti adalah membahas tentang Meningkatkan minat baca siswa.Dengan demikian, maka tingkat minat baca siswa mengalami hubungan yang signifikan kearah yang positif. Siswa yang dijadikan sampel tersebut secara bertahap diberikan pemantauan, hal ini dapat dilihat dari 9 sekolah yang dijadikan sampel dalam penelitian ini yang diberikan kuisioner mengenai korelasi antara tingkat minat baca dengan kompetensi pengetahuan PKn sebanyak 159 siswa dengan perhitungan rerata 80 berada pada kategori Baik.

\section{KESIMPULAN}

Berdasarkan analisis korelasi sederhana hasil sebesar $r_{x y}$ hitung $(0.960)>r_{\text {tabel }}(0.130)$ yang artinya terdapat hubungan yang signifikan dengan kategori hubungan sangat kuat dengan nilai arah yang koefisien regresi bernilai positif.Hal ini dapat diartikan, semakin tinggi kompetensi pengetahuan Pendidikan Kewarganegaraan siswa maka semakin tinggi pula tingkat minat baca siswa.Beberapa saran yang ingin peneliti sampaikan kepada siswa yaitu agar dapat memperkuat tingkat minat baca siswa sehinggaakanlebih mudah dan lebih banyak dalam menambah wawasan dalam meningkatkan kompetensi pengetahuan Pendidikan Kewarganegaraan siswa.Sedangkan untuk para guru serta pengajar lainnya agar penelitian ini dapat dijadikan masukan bahwa kompetensi pengetahuan Pendidikan Kewarganegaraan dipengaruhi oleh minat baca sehingga guru dapat menciptkan suasana kegiatan pembelajaran yang menugaskan dan melibatkan siswa lebih banyak untuk membaca (literasi) dan berdiskusi terutama dalam pembelajaran Pendidikan Kewarganegaraan.

\section{DAFTAR PUSTAKA}

Agung, A. A. G. (2014). Metodologi Penelitian Pendidikan. Aditya Media Publishing.

Andayani, N. P. R., Asri, I. G. A. A. S., \& Suniasih, N. W. (2019). Pengaruh Model Pembelajaran Jigsaw Berbasis Penilaian Portofolio Terhadap Kompetensi Pengetahuan PKn. Jurnal Pedagogi Dan Pembelajaran, 2(3), 325-332.

Arum Nisma Wulanjani, \& Candradewi Wahyu Anggraeni. (2019). Meningkatkan Minat Membaca melalui Gerakan Literasi Membaca bagi Siswa Sekolah Dasar. Proceeding of Biology Education, 3(1), 2631. https://doi.org/10.21009/pbe.3-1.4

Depdiknas. (2003). Kurikulum 2004 Standar Kompetensi untuk Kelas V Sekolah Dasar. Depdiknas.

Finisea, E. M., \& Fajriyah, K. (2010). Analisis Korelasi Minat Baca Dengan Kemampuan Menemukan Pokok Pikiran Paragraf Pada Siswa Sekolah Dasar. 024.

Gunawan, A., \& Ign. Wagimin, P. N. (2013). Korelasi Antara Karakter Pribadi dan Minat Membaca dengan Prestasi Belajar Siswa Arwan. Journal of Petrology, 369(1), 1689-1699. https://doi.org/10.1017/CB09781107415324.004

KARIADI, D., \& SUNARSO. (2016). Pengaruh Minat Baca, Waktu Belajar, Sarana Prasarana dan Kemampuan Mengajar Guru Terhadap Hasil Belajar PKN. Jurnal Ilmu -Ilmu Sosial, Vol.13, No.

Kasiyun, S. (2015). Upaya Meningkatkan Minat Baca Sebagai Sarana Untuk Mencerdaskan Bangsa. Bahasa Indonesia,Sastra, Dan Pengajarannya, 1.

Kunandar, D. (2013). Penilaian Autentik (Penilaian Hasil Belajar Peserta Didik Berdasarkan Kurikulum 2013) Suatu Pendekatan Praktis (Edisi Revisi). Jakarta: PT Rajagrafindo Persada.

Lestari, N. M. D., Suniasih, N. W., \& Darsana, I. W. (2017). Pengaruh Model Pembelajaran Snowball Throwing Berbasis Lagu-lagu Anak Terhadap Kompetensi Pengetahuan PKN. Journal of Education Technology, 1(3), 163-168. 
Novrizta, D. (2018). Hubungan Antara Minat Membaca Dengan Keterampilan Menulis Karangan Narasi Siswa Sekolah Dasar. Jurnal Review Pendidikan Dan Pengajaran, 1(1), 104-124.

Nurhaidah, \& Musa, M. I. (2015). Pelayanan Pendidikan Yang Berkualitas Di Era Global Dalam Mengembangkan Potensi Peserta Didik Secara Maksimal. 1(4), 52-65.

Permendikbud. (2014). Permendikbud Nomor 57 Tahun 2014. Kementerian Pendidikan dan Kebudayaan.

Renda, N. T., \& Widiastini, N. W. E. (2017). Pembelajaran PPKn SD. Fakultas Ilmu Pendidikan Universitas Pendidikan Ganesha.

Ruslan, \& Wibayanti, S. H. (2019). Pentingnya Meningkatkan Minat Baca Siswa. Prosiding Seminar Nasional Pendidikan Program Pascasarjana Universitas PGRI Palembang 12 JANUARI 2019, 767-775.

Salma, A. (2019). Analisis Gerakan Literasi Sekolah Terhadap Minat Baca Siswa Siswa Sekolah Dasar. MIMBAR PGSD Undiksha, 7(2).

Sari, J. N. (2016). Hubungan antara Minat Baca dengan Hasil Belajar IPS Siswa Kelas V SD Negeri di Kecamatan Mijen Kota Semarang. E-Journal Mimbar PGSD Universitas PGRI Semarang Maret, 7(2).

Slameto, S. (2010). Belajar dan faktor yang mempengaruhinya. Jakarta: Rineka Cipta.

Sudarsana, U. (2014). Pembinaan Minat Baca. Alfabeta.

Sugiyono. (2015). Metode Penelitian Pendidikan Kuantitatif, Kualitatif Dan R\&D. Alfabeta.

Syardiansah. (2016). Hubungan Motivasi Belajar dan Minat Belajar terhadap Prestasi Belajar Mahasiswa Mata Kuliah Pengantar Manajemen ( Studi kasus Mahasiswa Tingkat I EKM A Semester II ). Jurnal Manajemen Dan Keuangan, 5(1), 443.

Utami, P., \& Bakhtaruddin. (2012). Peranan Perpustakaan Sekolah Dalam Meningkatkan Minat Baca Siswa SDIT Iqra' Kota Solok. September, 270-273.

Wahadaniyah, H. (n.d.). Perpustakaan Sekolah Sebagai Sarana Pengembangan Minat dan Kegemaran Membaca.

Yaumi, M. (2017). Prinsip-prinsip desain pembelajaran: Disesuaikan dengan kurikulum 2013 edisi Kedua. Kencana. 